Article

\title{
Proximate Composition, Nutritional Attributes and Mineral Composition of Peperomia pellucida L. (Ketumpangan Air) Grown in Malaysia
}

\section{Der-Jiun Ooi ${ }^{1}$, Shahid Iqbal ${ }^{1,2}$ and Maznah Ismail ${ }^{1,3, *}$}

1 Laboratory of Molecular Biomedicine, Institute of Bioscience, Universiti Putra Malaysia, UPM Serdang 43400, Selangor, Malaysia; E-Mails: ooiderjiun@gmail.com (D.-J.O.); ranashahid313@gmail.com (S.I.)

2 Department of Chemistry, University of Sargodha, Sargodha 40100, Pakistan

3 Department of Nutrition and Dietetic, Faculty of Medicine and Health Sciences, Universiti Putra Malaysia, UPM Serdang 43400, Selangor, Malaysia

* Author to whom correspondence should be addressed; E-Mail: maznah@medic.upm.edu.my; Tel.: +603-8947-2115; Fax: +603-8947-2116.

Received: 19 July 2012; in revised form: 8 August 2012 / Accepted: 22 August 2012 /

Published: 17 September 2012

\begin{abstract}
This study presents the proximate and mineral composition of Peperomia pellucida L., an underexploited weed plant in Malaysia. Proximate analysis was performed using standard AOAC methods and mineral contents were determined using atomic absorption spectrometry. The results indicated Peperomia pellucida to be rich in crude protein, carbohydrate and total ash contents. The high amount of total ash $(31.22 \%)$ suggests a high-value mineral composition comprising potassium, calcium and iron as the main elements. The present study inferred that Peperomia pellucida would serve as a good source of protein and energy as well as micronutrients in the form of a leafy vegetable for human consumption.
\end{abstract}

Keywords: Peperomia pellucida; proximate composition; mineral profile

\section{Introduction}

Peperomia pellucida L. (Piperaceae), a common annual weed native to tropical North and South America, is now pantropic in distribution and is abundantly available in Malaysia. Locally, it is 
variously known as sirih cina, ketumpangan air, tumpang angin or căo hú jīao. In other parts of the world, it is known as pak-krasang (Thailand), càng cua (Vietnam), pansit-pansitan or ulasimang bato (Philippines), silverbush, man-to-man, pepper elder or rat ear (North America), kaca-kaca or surukan (Indonesia), usuba sunakosho (Japan), alumbre or erva-de-vidro (Spain), mashitandu chedi, pononoa, toyakandha or varshabhoo (India), pépéromie or herbe à couleuvre (France) and luchi pata (Bangladesh). The plant flourishes in moist as well as in shady areas and can grow up to height of 15 to $45 \mathrm{~cm}$. $P$. pellucida is characterized by its smooth, fleshy and heart-shaped leaves, succulent stems, shallow roots and minute flowers, which eventually grow into numerous tiny seeds attaching on the cord-like spikes [1].

The plant has been widely used for different medicinal purposes and has been used culturally for a variety of ailments including conjunctivitis, convulsions, fatigue, fever, headache, gout, rheumatic pains, skin diseases, to lower blood cholesterol level and breast cancer [1]. Its properties have been further affirmed by a number of research reports. Aerial parts of $P$. pellucida demonstrated dose-dependent analgesic and anti-inflammatory actions by interfering with prostaglandin synthesis [2-4]. Khan et al. $[5,6]$ reported a dose-dependent depressant effect and antipyretic effect of $P$. pellucida leaf comparable to standard aspirin, while Mutee et al. [4] presented the potential use of the plant as an antioxidative agent. Nwokocha et al. [7] suggested a dose-dependent hypotensive effect of $P$. pellucida via enhancement of endothelial nitric oxide (NO)-dependent vasorelaxation. P. pellucida leaf also exhibited broad spectrum bactericidal [8] and fungicidal activity against Helminthosporium oryzae [9] and Trichophyton mentagrophytes [10].

Previous phytochemical analyses on this plant revealed the presence of flavonoids, apiols, phytosterols, substituted styrenes, secolignans, tetrahydrofuran lignans, arylpropanoids, sesamin, isoswertisin, xanthone glycoside and peperomins A, B, C and E in it. Arylpropanoids, peperomins and patuloside A (which is a type of xanthone glycoside) exhibited antifungal, anticancer and antibacterial activities, respectively [10-12].

It is an edible plant and is frequently used as a leafy vegetable or condiment in many parts of the tropics. Egwuche et al. [13] reported the proximate and mineral composition of P. pellucida leaf. Although some preliminary information has been presented in an earlier report, but detailed investigations are still required as P. pellucida is being consumed on a major scale and is traditionally prescribed as folk medicine in the whole plant form. No report on the nutritional and mineral profile of P. pellucida, indigenous to Malaysia, has been presented so far. Nutritional composition and phytochemical properties are reported to vary with agroclimatic conditions, humidity and species of the plant [14]. This study was, therefore, carried out to determine the proximate composition and mineral contents in P. pellucida whole plant collected from Malaysia.

\section{Results and Discussion}

The findings for proximate composition of P. pellucida whole plant are presented in Table 1 . The moisture content of fresh whole plant $P$. pellucida was found to be $93.14 \%$, contributed by the bulk tissue weight of fleshy and succulent stem. After oven drying, the P. pellucida whole plant still contained a moisture level with a mean value of $8.33 \%$. The high water content in P. pellucida makes it ideal for vegetable juicing as a supplement to whole vegetables. Nevertheless, in terms of natural 
product stability, high moisture content tends to promote microbial contamination and chemical degradation [15], as it provides a medium for many reactions to occur.

Table 1. Proximate composition of Peperomia pellucida.

\begin{tabular}{cc}
\hline Analysis & Mean \pm SD \\
\cline { 1 - 2 } Proximate analysis (g/100 g DW) & \\
\hline Moisture & $8.33 \pm 0.33$ \\
Protein & $10.63 \pm 0.07$ \\
Lipid & $3.24 \pm 0.28$ \\
Carbohydrates & $46.58 \pm 2.74$ \\
Total ash & $31.22 \pm 2.06$ \\
Caloric value $(\mathrm{kcal} / \mathrm{kJ})$ & $258 / 1080$ \\
\hline
\end{tabular}

Each value represents the mean \pm SD of three determinations on dry weight $(\mathrm{DW})$ basis.

The protein and lipid contents of the whole plant were 10.63 and 3.24\%, respectively. Protein content of $P$. pellucida is comparable to that of other leafy vegetables, where the protein content ranged from 1 to $7 \%$ of fresh weight or 8 to $30 \%$ of dry weight basis [16]. The major components of P. pellucida oil had been reported to be dillapiole and trans-caryophyllene [17,18] where trans-caryophyllene had previously exhibited anti-inflammatory action in mice [19]. The caloric value of $P$. pellucida was found to be $258 \mathrm{kcal} / 100 \mathrm{~g}$ DW; indicating it could be an important source of energy. The carbohydrate level (46.58\%) was the highest calorie contributor, as the total lipid and protein contents did not considerably affect the determination of energy produced.

The ash content is generally recognized as a measure of quality for the assessment of the functional properties of foods [20]. P. pellucida contained high levels of total ash, up to $31.22 \%$, in the dried plant. This, in turn, indicated a high content of minerals such as potassium $(6,977 \mathrm{mg} / 100 \mathrm{~g} \mathrm{DW})$, followed by calcium (483 mg/100 $\mathrm{g} \mathrm{DW})$ and iron $(119.3 \mathrm{mg} / 100 \mathrm{~g} \mathrm{DW})$. The mineral profile of P. pellucida whole plant is shown in Table 2. The high content of potassium compared to sodium led to a very low $\mathrm{Na} / \mathrm{K}$ ratio, which is favorable from nutritional point of view, as diets with low $\mathrm{Na} / \mathrm{K}$ ratio are associated with lower incidence of hypertension [21]. This may explain the nitric oxide (NO)-dependent hypotensive effect reported by Nwokocha et al. [7] and the rationale behind the traditional use of the plant in managing hypertension [22]. Calcium was found to be the second most abundant mineral element present in this plant. Therefore $P$. pellucida can be considered an appropriate dietary source of calcium to maintain the biological role of nerve transmission, muscle contraction, glandular secretion as well as mediating vascular contraction and vasodilation [23].

Iron deficiency is a common nutritional problem affecting many people worldwide. Primarily, it occurs as a result of chronic bleeding, infections, inadequate intake of bioavailable iron, deficiencies of folic acid, vitamin $\mathrm{A}$ or vitamin $\mathrm{B}_{12}$, pregnancy, increased requirements throughout growing periods and menstrual losses in women during reproductive age. The high amount of iron found in P. pellucida indicated that the plant could be a good source of dietary iron to overcome nutritional deficiency of iron, if supplemented in the diet. 
Table 2. Mineral composition of Peperomia pellucida.

\begin{tabular}{cc}
\hline Analysis & Mean \pm SD \\
\hline Minerals (mg/100 g DW) & $6977 \pm 4.24$ \\
Potassium & $483 \pm 97.02$ \\
Calcium & $119.3 \pm 20.33$ \\
Iron & $53.92 \pm 0.37$ \\
Sodium & $12.59 \pm 0.25$ \\
Zinc & $3.10 \pm 0.33$ \\
Copper &
\end{tabular}

Values are means \pm SD calculated as milligram per 100 gram dry weight (DW) for Peperomia pellucida analyzed individually in triplicate.

Copper and zinc are the essential trace elements that are needed only in minute amounts by the human body for important biochemical functions. The levels of copper and zinc are closely interrelated. Zinc stimulates the synthesis of metallothionein. Metallothionein has a high affinity for copper and it hinders copper systemic absorption within the intestinal cells [24]. Excessive ratio of zinc to copper $(>16)$ from dietary sources causes imbalance in their bioavailability and has been linked to increased risk of cardiovascular system disorders [25]. The recommended zinc/copper ratio in human tissues is four to six [26,27]. P. pellucida, with its zinc/copper ratio of four, represents a potential food source to counter copper-zinc imbalances.

\section{Experimental}

\subsection{Procurement and Preparation of Plant Materials}

Peperomia pellucida (L.) plant was harvested as one batch from Guar Chempedak, Kedah, Malaysia. The collected plant sample was washed under running tap water, rinsed with distilled water and oven-dried at $40{ }^{\circ} \mathrm{C}$ for $48 \mathrm{~h}$ using a material test chamber M720 (Binder $\mathrm{GmbH}$, Tuttlingen, Germany). Obtained dry matter was ground to a fine powder, sifted in a sieve $(35 \mathrm{~mm})$ and stored at $-20^{\circ} \mathrm{C}$ in air-tight containers till further analyses.

\subsection{Proximate Analyses}

\subsubsection{Moisture}

Moisture content was measured using air-oven following official methods of Association of Official Analytical Chemists [28]. A material test chamber M720 (Binder GmbH, Tuttlingen, Germany) was used to dry the samples till constant weight. The percentage of moisture content was calculated as:

$$
\% \text { Moisture }=\left(1-\frac{\text { Weight }_{\text {dry dample }}}{\text { Weight }_{\text {wet sample }}}\right) \times 100
$$

\subsubsection{Lipid}

Determination of lipid content was performed following Soxtec method previously described by Noureddini and Byun [29], using a Soxtec ${ }^{\mathrm{TM}} 2050$ automated analyzer (FOSS Analytical, Hillerød, 
Denmark). Petroleum ether was used for the extraction, whereas percentage of lipid was obtained following equation below:

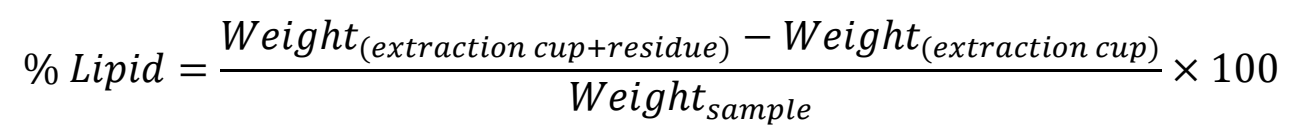

\subsubsection{Protein}

The total nitrogen amount in the sample was determined according to method described by $\mathrm{Ng}$ et al. [30] using Kjeltec ${ }^{\mathrm{TM}} 2200$ Auto Distillation Unit (FOSS Tecator, Höganäs, Sweden). A nitrogen-to-protein conversion factor of 4.4 was used for the determination of protein present in the samples.

\subsubsection{Ash Content and Ash Solution}

A dry ashing method was used to determine the ash content [28]. The samples were incinerated in a furnace (Furnace 62700, Barnstead/Thermolyne, Dubuque, IA, USA) at $550{ }^{\circ} \mathrm{C}$. The remaining inorganic material was cooled, weighed and further used for the determination of mineral contents. An ash solution was prepared by dissolving the ash in $100 \mathrm{~mL}$ of $1 \mathrm{M} \mathrm{HCl}$.

\subsubsection{Carbohydrate and Caloric Value}

The total carbohydrate content (\%) in the samples was calculated by difference method. The caloric value was calculated by sum of the percentages of proteins and carbohydrates multiplied by a factor of $4(\mathrm{kcal} / \mathrm{g})$ and total lipids multiplied by a factor of $9(\mathrm{kcal} / \mathrm{g})$.

\subsection{Mineral Analyses}

A NOVA 400 atomic absorption spectrometer (Analytik Jena AG, Jena, Germany) with an air/acetylene flame and respective hollow-cathode lamps was used for absorbance measurements. Wavelengths, slits and lamp current used for the determination of six elements were $213.9 \mathrm{~nm}, 0.5 \mathrm{~nm}$, $4.0 \mathrm{~mA}$ (zinc); $422.7 \mathrm{~nm}, 1.2 \mathrm{~nm}, 4.0 \mathrm{~mA}$ (calcium); $324.8 \mathrm{~nm}, 1.2 \mathrm{~nm}, 3.0 \mathrm{~mA}$ (copper); $589.0 \mathrm{~nm}$, $0.8 \mathrm{~nm}, 3.0 \mathrm{~mA}$ (sodium); $248.3 \mathrm{~m}, 0.2 \mathrm{~nm}, 6.0 \mathrm{~mA}$ (iron) and $766.5 \mathrm{~nm}, 0.8 \mathrm{~nm}, 4.0 \mathrm{~mA}$ (potassium), respectively. The results for mineral contents were expressed as $\mathrm{mg} / 100 \mathrm{~g} \mathrm{DW}$.

\subsection{Statistical Analysis}

Statistical analyses were conducted using GraphPad Prism (San Diego, CA, USA) version 5.02 for Windows. All the determinations were carried out in triplicate and data were expressed as mean \pm standard deviation.

\section{Conclusions}

In conclusion, the potential of $P$. pellucida as an important source of nutritional and mineral compounds in the tropics is highlighted in the present study. In line with increasing global demand for food, $P$. pellucida finds use as potential source of functional foods. 


\section{References}

1. Mosango, D.M. Peperomia pellucida (L.) Kunth. In Prota 11(1): Medicinal Plants/Plantes médicinales 1; Schmelzer, G.H., Gurib-Fakim, A., Eds.; PROTA: Wageningen, The Netherlands, 2008.

2. Aziba, P.I.; Adedeji, A.; Ekor, M.; Adeyemi, O. Analgesic activity of Peperomia pellucida aerial parts in mice. Fitoterapia 2001, 72, 57-58.

3. DeFatima, A.B.M.; Dmitrieva, E.G.; Franzotti, E.M.; Antoniolli, A.R.; Andrade, M.R.; Marchiori, M. Anti-inflammatory and analgesic activity of Peperomia pellucida (L.) H.B.K. (Piperaceae). J. Ethnopharmacol. 2004, 91, 215-218.

4. Mutee, A.F.; Salhimi, S.M.; Yam, M.F.; Lim, C.P.; Abdullah, G.Z.; Ameer, O.Z.; Abdulkarim, M.F.; Asmawi, M.Z. In vivo anti-inflammatory and in vitro antioxidant activities of Peperomia pellucida. Int. J. Pharmacol. 2010, 6, 686-690.

5. Khan, A.; Rahman, M.; Islam, M.S. Antipyretic activity of Peperomia pellucida leaves in rabbit. Turk. J. Biol. 2008, 32, 37-41.

6. Khan, A.; Rahman, M.; Islam, M.S. Neuropharmacological effects of Peperomia pellucida leaves in mice. DARU J. Pharm. Sci. 2008, 16, 35-40.

7. Nwokocha, C.R.; Owu, D.U.; Kinlocke, K.; Murray, J.; Delgoda, R.; Thaxter, K.; McCalla, G.; Young, L. Possible mechanism of action of the hypotensive effect of Peperomia pellucida and interactions between human cytochrome P450 enzymes. Med. Aromat. Plants 2012, 1, 105. doi:10.4172/2167-0412.1000105.

8. Khan, M.R.; Omoloso, A.D. Antibacterial activity of Hygrophila stricta and Peperomia pellucida. Fitoterapia 2002, 73, 251-254.

9. Singh, A.K.; Dikshit, A.; Dixit, S.N. Antifungal studies of Peperomia pellucida. Beitr. Biol. Pflanz. 1983, 58, 357-368.

10. Ragasa, C.Y.; Dumato, M.; Rideout, J.A. Antifungal compounds from Peperomia pellucida. ACGC Chem. Res. Commun. 1998, 7, 54-61.

11. Khan, A.; Rahman, M.; Islam, M.S. Isolation and Bioactivity of a Xanthone Glycoside from Peperomia pellucida. Life Sci. Med. Res. 2010, 2010, LSMR-1.

12. Xu, S.; Li, N.; Ning, M.M.; Zhou, C.H.; Yang, Q.R.; Wang, M.W. Bioactive compounds from Peperomia pellucida. J. Nat. Prod. 2006, 69, 247-250.

13. Egwuche, R.U.; Odetola, A.A.; Erukainure, O.L. Preliminary investigation into the chemical properties of Peperomia pellucida L. Res. J. Phytochem. 2011, 5, 48-53.

14. Iqbal, S.; Bhanger, M.I. Effect of season and production location on antioxidant activity of Moringa oleifera leaves grown in Pakistan. J. Food Comp. Anal. 2006, 19, 544-551.

15. Hussain, K.; Ismail, Z.; Sadikun, A.; Ibrahim, P. Proximate and qualitative analysis of different parts of Piper sarmentosum, and quantification of total amides in various extracts. Phcog. Res. 2009, 1, 113-119.

16. Uusiku, N.P.; Oelofse, A.; Duodu, K.G.; Bester, M.J.; Faber, M. Nutritional value of leafy vegetables of sub-Saharan Africa and their potential contribution to human health: A review. J. Food Comp. Anal. 2010, 23, 499-509. 
17. DaSilva, M.H.L.; Zoghbi, M.G.B.; Andrade, E.H.A.; Maia, J.G.S. The essential oils of Peperomia pellucida Kunth and P. circinnata Link var. circinnata. Flavour Fragr. J. 1999, 14, 312-314.

18. DeLira, P.N.B.; DaSilva, J.K.R.; Andrade, E.H.A.; Sousa, P.J.; Silva, N.N.S.; Maia, J.G.S. Essential oil composition of three Peperomia species from the Amazon, Brazil. Nat. Prod. Commun. 2009, 4, 427-430.

19. Fernandes, E.S.; Passos, G.F.; Medeiros, R.; Cunha, F.M.D.; Ferreira, J.; Campos, M.M.; Pianowski, L.F.; Calixto, J.B. Anti-inflammatory effects of compounds alpha-humulene and (-)-trans-caryophyllene isolated from the essential oil of Cordia verbenacea. Eur. J. Pharmacol. 2007, 569, 228-236.

20. Hofman, P.J.; Vuthapanich, S.; Whiley, A.W.; Klieber, A.; Simons, D.H. Tree yield and fruit minerals concentrations influence "Hass" avocado fruit quality. Sci. Hort. 2002, 92, 113-123.

21. Choi, M.; Scholl, U.I.; Yue, P.; Bjorklund, P.; Zhao, B.; Nelson-Williams, C.; Ji, W.; Cho, Y.; Pael, A.; Men, C.J.; et al. K+ channel mutations in adrenal aldosterone-producing adenomas and hereditary hypertension. Science 2011, 331, 768-772.

22. Mensah, J.K.; Okoli, R.I.; Turay, A.A.; Ogie-Odia, E.A. Phytochemical analysis of medicinal plants used for the management of hypertension by Esan people of Edo state, Nigeria. Ethnobotanical Leaflets 2009, 13, 1273-1287.

23. Straub, D.A. Calcium supplementation in clinical practice: A review of forms, Doses and indications. Nutr. Clin. Pract. 2007, 22, 286-296.

24. Osredkar, J.; Sustar, N. Copper and zinc, Biological role and significance of copper/zinc imbalance. J. Clinic. Toxicol. 2011, S3, 001. doi:10.4172/2161-0495.S3-001.

25. Ma, J.; Netts, N.M. Zinc and copper intakes and their major food sources for older adults in the 1994-96 continuing survey of food intakes by individuals (CSFII). J. Nutr. 2000, 130, 2838-2843.

26. Klevay, L.M. The ratio of zinc to copper of diets in the United States. Nutr. Rep. Int. 1975, 11, 237-242.

27. King, J.C.; Cousins, R.J. Zinc. In Modern Nutrition in Health and Disease, 10th ed.; Shils, M.E., Shike, M., Ross, A.C., Caballero, B., Cousins, R.J., Eds.; Lippincott Williams and Wilkins: Baltimore, MD, USA, 2006; pp. 271-285.

28. Association of Official Analytical Chemists (AOAC). Official Methods of Analysis of AOAC International, 17th ed; AOAC International: Gaithersburg, MD, USA, 2000.

29. Noureddini, H.; Byun, J. Dilute-acid pretreatment of distillers' grains and corn fiber. Bioresource Technol. 2010, 101, 1060-1067.

30. Ng, E.C.; Dunford, N.T.; Chenault, K. Chemical characteristics and volatile profile of genetically modified peanut cultivars. J. Biosci. Bioeng. 2008, 106, 350-356.

Sample Availability: Samples are available from the authors.

(C) 2012 by the authors; licensee MDPI, Basel, Switzerland. This article is an open access article distributed under the terms and conditions of the Creative Commons Attribution license (http://creativecommons.org/licenses/by/3.0/). 